\title{
Abdominal Obesity in Overweight Schoolchildren from Portoviejo (Ecuador). Conicity Index Cut-Points for Sustainable Health
}

\author{
Ricardo Arencibia-Moreno ${ }^{1}$, Damaris Hernández-Gallardo ${ }^{2}$, Daniel Linares-Girela ${ }^{3}$, \\ Johanna Sabrina Párraga-Acosta ${ }^{1}$, José Gabriel Pilay-Chávez ${ }^{1}$ (D) and Marta Linares-Manrique ${ }^{4, *}$ \\ 1 Faculty of Health Sciences, Technical University of Manabí, Portoviejo 130108, Ecuador; \\ ricardo.arencibia@utm.edu.ec (R.A.-M.); johanna.parraga@utm.edu.ec (J.S.P.-A.); \\ jose.pilay@utm.edu.ec (J.G.P.-C.) \\ 2 Faculty of Educational Sciences, Civil University Eloy Alfaro of Manabí, Manta 130802, Ecuador; \\ damaris.hernandez@uleam.edu.ec \\ 3 Physical Anthropology Laboratory, Faculty of Medicine, University of Granada, 18071 Granada, Spain; \\ dlinares@ugr.es \\ 4 Faculty of Health Sciences, University Campus of Melilla, University of Granada, 52071 Melilla, Spain \\ * Correspondence: mlinar@ugr.es; Tel.: +34-651-63-56-25
}

check for updates

Citation: Arencibia-Moreno, R.; Hernández-Gallardo, D.; Linares-Girela, D.; Párraga-Acosta, J.S.; Pilay-Chávez, J.G.; Linares-Manrique, M. Abdominal Obesity in Overweight Schoolchildren from Portoviejo (Ecuador). Conicity Index Cut-Points for Sustainable Health. Sustainability 2021, 13, 5583. https://doi.org/ $10.3390 /$ su13105583

Academic Editors: Pedro Valdivia-Moral and Jose Luis Ubago

Received: 15 March 2021

Accepted: 14 May 2021

Published: 17 May 2021

Publisher's Note: MDPI stays neutral with regard to jurisdictional claims in published maps and institutional affiliations.

Copyright: (C) 2021 by the authors Licensee MDPI, Basel, Switzerland. This article is an open access article distributed under the terms and conditions of the Creative Commons Attribution (CC BY) license (https:// creativecommons.org/licenses/by/ $4.0 /)$.

\begin{abstract}
Background: Abdominal obesity describes the accumulation of visceral fat. Monitoring of abdominal obesity in children aids prognosis of atherogenic risk and prediction of the emergence of different comorbidities, many of which persist into and throughout adulthood. For this reason, it is of great diagnostic value to the sustainability of health in populations. The aim of this study was to evaluate abdominal obesity in overweight schoolchildren from Portoviejo (Ecuador) and propose conicity index cut-points for sustainable health. (2) Methods: The sample was formed by 356 schoolchildren whose BMI z-score deemed them to be overweight. Height, weight, waist circumference (wstC), various skinfolds, percent body fat, conicity index $(\mathrm{CI})$ and overweight classification according to wstC were determined. (3) Results: The mean age was $6.83 \pm 1.2$ years, $17.4 \%$ were obese, $34.8 \%$ were overweight and $47.8 \%$ were at risk of being overweight according to their BMI z-score. The mean height was $1.29 \pm 0.12 \mathrm{~m}$, whilst the mean weight was $35.21 \pm 11.57 \mathrm{~kg}$. When classifying according to wstC, $37.9 \%$ were identified as obese, $28.1 \%$ had high-risk abdominal adiposity and $34 \%$ were normal. The average CI was $1.16 \pm 0.06$, whilst that of body fat was $19.34 \pm 6.03$, with $56.2 \%$ of individuals having body fat values lower than $20 \%$. (4) Conclusions: The sample showed a high prevalence of central obesity. Significant agreement was not found between classifications of nutritional status according to BMI z-score and wstC.
\end{abstract}

Keywords: abdominal obesity; children; nutritional status; body mass index; sustainable health; lifestyle

\section{Introduction}

In contemporary society, hedonic desires for foodstuffs, food marketing [1] and sedentary lifestyles [2] are the main causes of excess weight, expressed as overweight and obesity. Detection and prevention at early ages are key to avoiding health sequalae in individuals, whilst the identification of physiological and behavioural causes is also urged. In this sense, from the standpoint of immediate practice, it is necessary to identify indicators that reveal the existence of risk associated with the distribution of body fat [3,4].

According to Fariñas Rodríguez et al. [5], the determination of body fat mass and its distribution in human beings is of great importance due to its predictive value with regard to morbidity. In fact, two individuals with the same amount of body fat may present differences in the fat content found in their abdominal stores. 
This situation is produced due to the intervention of diverse synergistic factors, such as the individual's genotype and their dietary habits. With regard to genotype, authors such as Lamiquiz-Moneo et al. [6] state that this explains between $50 \%$ and $70 \%$ of the variability seen in excess weight. However, it is also important to consider dietary habits, which, in the sense that they are behavioural choices, are integrated into individuals' lifestyles. These habits often drive dietary energy intake to continuously displace energy balance towards positive values [7], with this generating a greater accumulation of visceral fat according to criteria laid out by Prazares Almeida et al. [8] and Hernández et al. [9].

In this sense, the reviewed literature demonstrates that the accumulation of excessive visceral fat could be considered as an atherogenic risk factor and, therefore, a path towards greater risk of suffering different comorbidities [5,10]. Further, according to BarretoQuintana et al. [11] and Ruiz Sánchez et al. [12], it may also function as a characteristic symptom of metabolic syndrome in children and adults and, therefore, lead to negative effects with regard to the sustainability of health.

The components of health sustainability are explained by Dornhoff et al. [13]. These include a social dimension and are incorporated into a feeding model which impacts upon the body composition of human beings. For this reason, preserving a positive health status is intimately related with lifestyle-related feeding types [14] and control over the bodily changes these provoke.

Indeed, the effectiveness of nutritional dietary treatments, such as those applied to abdominal obesity, depends on their acceptance and adherence by schoolchildren [15]. From this, we can see the notable importance of an early diagnosis of nutritional status in children. This is crucial not only for personalising nutritional therapy but, also, for favouring the promotion and application of prevention and education programs, which provide training and develop student responsibility both towards themselves and towards sustainable health.

Amongst the different anthropometric indicators used to determine abdominal adiposity, it is relevant to mention waist circumference [16] and the conicity index [17]. With regard to the latter various authors have highlighted that there is a lack of studies reporting use of this indicator with children [5,9]. Further, there is a lack of consensus regarding its use as a predictor within this group [18-20]. In relation to the present line of research, it also is relevant to mention that no published manuscripts exist that report its use in Ecuador.

In consideration of the points presented above and the significance to health of body fat distribution, the aim of the present study was to evaluate abdominal obesity in schoolchildren with excess weight in Portoviejo (Ecuador). The study aimed to propose conicity index cut-points for sustainable health.

\section{Materials and Methods}

\subsection{Design}

A descriptive, observational and cross-sectional study was conducted with a population of schoolchildren from seven educational units (centres for below baccalaureate-level academic study) in Portoviejo Canton (Ecuador). All participants underwent nutritional screening within the context of the "strategy for improving nutritional status in 5-9-yearold students attending state and private schools in the north central coastal region of Ecuador" (Reference: UTM Folio AP-C1-2018-FCS-0003).

\subsection{Participants}

The population was formed by 1760 schoolchildren who were included in the aforementioned research project and underwent nutritional screening. Of these, study participants were selected using purposive and non-probabilistic sampling methods to which inclusion criteria were applied. Specifically, participants were selected who were classified as being obese, overweight or at risk of being overweight according to BMI/age/sex z-scores established by the World Health Organization [21]. In this way, a sample of 356 in- 
dividuals was provided for analysis. This sample was distributed post facto according to five age groups corresponding to five, six, seven, eight and nine years of age.

\subsection{Instruments}

With regard to anthropometric measurement, a number of instruments were used. A Siber-Hegner anthropometer (GPM, CH) was used to measure height to the closest $0.1 \mathrm{~cm}$. Weight was obtained using a Tanita InnerScan V Model scale (BC-545N) with $0.1 \mathrm{~kg}$ accuracy. Waist circumference was measured using a Lufkin W606PM (Lufkin, USA) nonextendable measuring tape, with measurements made possible to the nearest millimetre. Finally, skinfolds were determined using a Holtain Tanner/Whitehorse skinfold calliper (Holtain, UK) with $0.2 \mathrm{~mm}$ spacing and $10 \mathrm{~g} / \mathrm{mm}^{2}$ pressure.

\subsection{Procedure}

Anthropometric procedures were carried out in line with protocols established by the ISAK [22]. A prior request for attendance of the schoolchildren to programmed sessions was made to parents and legal guardians. Children were requested to attend in a fasted state, having evacuated their bowels as normal and bringing their breakfast foods with them. This was monitored by members of the research team. Measurements were taken between 07:00 and 09:00 h. Age was recorded for each participant, in addition to height $(\mathrm{H}$, $\mathrm{m})$, weight $(\mathrm{W}, \mathrm{kg}$ ), waist circumference (wstC, $\mathrm{m}$ ) and tricep (Pl Tri), subscapular (Pl Sub), supraespinal (Pl Sesp) and abdominal (Pl Abd) skinfolds in $\mathrm{mm}$.

The conicity index (CI) was calculated for each participant from the anthropometric variables of health, weight and waist circumference. The equation proposed by Valdez, Seidell, Ahn and Weiss [17] was used to make these calculations. These authors have also suggested that the index provides a useful anthropometric indicator for the evaluation of abdominal obesity. The $\mathrm{CI}$ in itself encapsulates waist circumference adjusted for weight and height [18]. It is expressed within a potential range of 1 to 1.73, where the former represents a perfect cylinder and pertains to individuals with little central or abdominal fat accumulation and the latter represents a perfect double cone, inverted at the base, reflecting excess abdominal fat $[9,23]$.

Depending on their CI value, participants were intentionally grouped into six groups, with groups classed according to $\mathrm{CI}$ increments of 0.1 , with the exception of the first $(\leq 1.00)$ and last $(\geq 1.41)$ groups.

Further, participating schoolchildren were classified in accordance with the waist circumferences pertaining to the categories describing obese, at risk of obesity and normal weight individuals, according to percentiles proposed by Fernández et al. [16].

Body fat percentage $(\mathrm{BF} \%)$ was determined for all participants using the sex-specific equations described by Faulkner [24]. Participants were later intentionally distributed between four groups depending on their body fat percentage. Groups pertained to body fat increments and covered 10 percentage points, with the exception of the first $(\leq 10.0 \%)$ and last $(\geq 30.01 \%)$ groups.

\subsection{Data Analysis}

Statistical analysis was performed using the software IBM SPSS version 23.0. Means $(\overline{\mathrm{X}})$ and standard deviations (SD) were determined. The normality of data was examined for continuous variables using the Kolmogorov-Smirnov and Shapiro-Wilk tests. Variance was analysed (F) and Tukey's test was used to compare the significance of individual mean comparisons. This method also enables variables to be grouped in accordance with a significance level of $\alpha=0.05$. Further, Pearson correlation coefficients were calculated for the associations produced between continuous variables and confidence intervals were determined for conicity indices according to the standard error of the mean $(\bar{X} \pm 1.96$ $\times$ standard error of the mean $\bar{X}$ ). All analyses were performed in line with the needs of the study. 
Comparative analysis was conducted for all continuous variables through Student's $t$-test $(t)$ and the Mann-Whitney $U$ test $(Z)$. Differences between categorical variables were examined according to the chi-squared statistic $\left(\mathrm{X}^{2}\right)$ and Cohen's kappa coefficient $(\mathrm{K})$. The latter also enabled the determination of the agreement between the classification methods used. Likewise, associations between variables were established according to Pearson correlations (r). In all cases, the significance level was set at $\alpha=0.05$.

Fieldwork was carried out by researchers who possessed internationally recognised qualifications in kineanthropometry and conducted data collection in pairs. With the aim of minimising measurement bias when recording variables, average values pertaining to first and second measurements were used. Next, the quality of recorded variables was established via variance analysis. This examined the significance of the technical error associated with anthropometric measurements and of confidence intervals according to the standard error of the mean $(\bar{X}) \pm 1.96 \times$ the standard error of the $(\bar{X})$. In cases of uncertainty, data were re-evaluated.

In order to carry out the work described above, informed consent was obtained from the parents or legal guardians of the schoolchildren under study. All processes were conducted in accordance with the ethical principles laid out in the Declaration of Helsinki and were performed under the supervision of the Bioethical Committee of the Technical University of Manabí.

\section{Results}

The mean age of the selected sample was $6.83 \pm 1.2$ years, with ages ranging between five and nine years. With regards to sex, $51.7 \%$ were boys and $48.3 \%$ were girls. Of these, $17.4 \%$ were obese, $34.8 \%$ were overweight and $47.8 \%$ were at risk of being overweight according to their BMI z-score [21].

The average height and weight are presented in Table 1. Both of these variables showed gradual increases with age and revealed that girls were taller and weighed more than boys, both overall and within each individual age group. The only exception was found amongst nine-year-olds, with boys showing higher measurements than girls, although these differences were not significant (Table 2).

Waist circumference gradually increased in schoolchildren with increasing age between five and nine years (Table 1). Nonetheless, it was demonstrated that six-year-old participants had greater waist circumferences than seven-year-olds but smaller waists than those aged eight years (Table 2). Analysis of variance showed these differences to be significant $(\mathrm{F}=16.035 ; p$-value $=0.000)$. Further, sex-based differences were established within the groups of participants aged six, eight and nine years, but not for five- and six-year-olds (Table 2).

The overall distribution pertaining to abdominal adiposity when determined via waist circumference is presented in Table 3 and reveals higher values in girls relative to boys in the categories pertaining to obesy the proposed modification is accepted it and being at risk of abdominal obesity.

Table 1. Overall values for direct and indirect anthropometric variables according to age group.

\begin{tabular}{cccccccc}
\hline Age & $\mathbf{n}=\mathbf{N 5 6}$ & $\begin{array}{c}\text { Height (m) } \\
\mathbf{n} \pm \mathbf{S D}\end{array}$ & $\begin{array}{c}\text { Weight (kg) } \\
\overline{\mathbf{X}} \pm \mathbf{S D}\end{array}$ & $\begin{array}{c}\text { Waist Circ. (cm) } \\
\overline{\mathbf{X}} \pm \mathbf{S D}\end{array}$ & $\begin{array}{c}\text { CI } \\
\overline{\mathbf{X}} \pm \mathbf{S D}\end{array}$ & $\begin{array}{c}\text { BF\% } \\
\mathbf{X} \pm \mathbf{S D}\end{array}$ \\
\hline 5 & 34 & 9.6 & $1.12 \pm 0.05$ & $23.95 \pm 3.86$ & $58.80 \pm 5.08$ & $1.17 \pm 0.05$ & $16.10 \pm 4.59$ \\
6 & 153 & 43.0 & $1.33 \pm 0.13$ & $39.34 \pm 14.08$ & $65.80 \pm 7.85$ & $1.16 \pm 0.06$ & $20.20 \pm 5.80$ \\
7 & 56 & 15.4 & $1.24 \pm 0.06$ & $32.29 \pm 6.33$ & $65.04 \pm 7.20$ & $1.17 \pm 0.05$ & $19.28 \pm 5.98$ \\
8 & 79 & 19.4 & $1.30 \pm 0.06$ & $34.93 \pm 5.98$ & $65.90 \pm 6.78$ & $1.17 \pm 0.06$ & $18.86 \pm 6.99$ \\
9 & 45 & 12.6 & $1.35 \pm 0.06$ & $40.18 \pm 10.07$ & $67.52 \pm 5.57$ & $1.15 \pm 0.05$ & $19.62 \pm 5.56$ \\
Total & 356 & 100 & $1.30 \pm 0.12$ & $36.22 \pm 11.76$ & $65.25 \pm 7.36$ & $1.16 \pm 0.06$ & $19.34 \pm 6.03$ \\
\hline
\end{tabular}


Table 2. Values for direct anthropometric variables and indices, according to sex and age. An examination of sex differences is also presented.

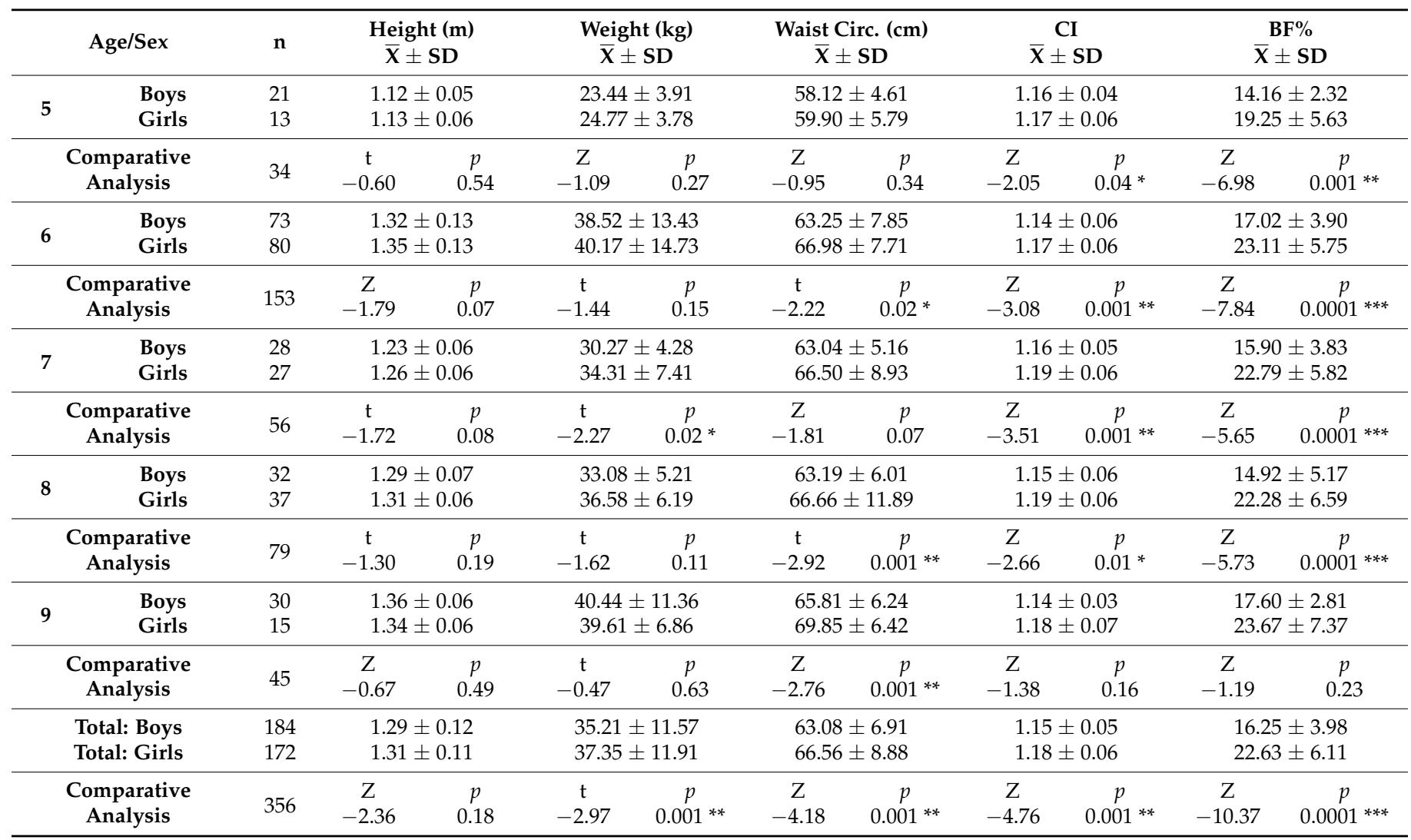

Note: (Z) Mann-Whitney U test, $(\mathrm{t})$ Student's $t$-test. Statistical significance: $\left({ }^{*}\right)<0.05 ;\left(^{* *}\right)<0.01 ;\left({ }^{* * *}\right)<0.001$.

Table 3. Distribution of nutritional status according to BMI z-score and abdominal obesity estimated from waist circumference, according to conicity index intervals.

\begin{tabular}{|c|c|c|c|c|c|c|c|c|c|}
\hline \multirow{2}{*}{ Sex } & \multirow{2}{*}{$\begin{array}{c}\text { CI } \\
\text { Intervals }\end{array}$} & \multicolumn{4}{|c|}{$\begin{array}{l}\text { Nutritional Status According to BMI } \\
\text { Z-Score }\end{array}$} & \multicolumn{4}{|c|}{$\begin{array}{l}\text { Abdominal Obesity According to Waist } \\
\text { Circumference }\end{array}$} \\
\hline & & $\begin{array}{l}\text { Obese } \\
\text { (\%) }\end{array}$ & $\begin{array}{l}\text { Overweight } \\
(\%)\end{array}$ & $\begin{array}{l}\text { Overweight } \\
\text { Risk (\%) }\end{array}$ & $\begin{array}{l}\text { Overall } \\
\quad(\%)\end{array}$ & $\begin{array}{l}\text { Obese } \\
(\%)\end{array}$ & $\begin{array}{c}\text { Abdominal } \\
\text { Obesity Risk (\%) }\end{array}$ & $\begin{array}{l}\text { Normal } \\
(\%)\end{array}$ & $\begin{array}{l}\text { Overall } \\
\quad(\%)\end{array}$ \\
\hline \multirow{7}{*}{ Boys } & $\leq 1.00$ & 0.0 & 0.0 & 0.5 & 0.5 & 0.0 & 0.0 & 0.5 & 0.5 \\
\hline & $1.01-1.10$ & 2.7 & 4.9 & 8.2 & 15.8 & 2.2 & 2.2 & 11.4 & 15.8 \\
\hline & $1.11-1.20$ & 10.9 & 21.2 & 34.2 & 66.3 & 14.7 & 18.5 & 33.2 & 66.3 \\
\hline & $1.21-1.30$ & 4.3 & 7.6 & 4.3 & 16.3 & 11.4 & 3.8 & 1.1 & 16.3 \\
\hline & $1.31-1.40$ & 0.0 & 0.5 & 0.0 & 0.5 & 0.5 & 0.0 & 0.0 & 0.5 \\
\hline & $1.41+$ & 0.5 & 0.0 & 0.0 & 0.5 & 0.5 & 0.0 & 0.0 & 0.5 \\
\hline & Total & 18.5 & 34.2 & 47.3 & 100 & 29.3 & 24.5 & 46.2 & 100 \\
\hline \multirow{6}{*}{ Girls } & $\leq 1.00$ & 0.0 & 0.0 & 0.6 & 0.6 & 0.0 & 0.0 & 0.6 & 0.6 \\
\hline & $1.01-1.10$ & 1.2 & 2.9 & 5.2 & 9.3 & 1.2 & 2.9 & 5.2 & 9.3 \\
\hline & $1.11-1.20$ & 6.4 & 16.9 & 33.7 & 57 & 17.4 & 24.4 & 15.1 & 57 \\
\hline & $1.21-1.30$ & 7.6 & 13.4 & 8.1 & 29.1 & 24.4 & 4.7 & 0.0 & 29.1 \\
\hline & $1.31-1.40$ & 1.2 & 2.3 & 0.6 & 4.1 & 4.1 & 0.0 & 0.0 & 4.1 \\
\hline & Total & 16.3 & 35.5 & 48.3 & 100 & 47.1 & 32 & 20.9 & 100 \\
\hline \multirow{7}{*}{ Overall } & $\leq 1.00$ & 0.0 & 0.0 & 0.6 & 0.6 & 0.0 & 0.0 & 0.6 & 0.6 \\
\hline & $1.01-1.10$ & 2 & 3.9 & 6.7 & 12.6 & 1.7 & 2.5 & 8.4 & 12.6 \\
\hline & $1.11-1.20$ & 8.7 & 19.1 & 34 & 61.8 & 16 & 21.3 & 24.4 & 61.8 \\
\hline & $1.21-1.30$ & 5.9 & 10.4 & 6.2 & 22.5 & 17.7 & 4.2 & 0.6 & 22.5 \\
\hline & $1.31-1.40$ & 0.6 & 1.4 & 0.3 & 2.2 & 2.2 & 0.0 & 0.0 & 2.2 \\
\hline & $1.41+$ & 0.3 & 0.0 & 0.0 & 0.3 & 0.3 & 0.0 & 0.0 & 0.3 \\
\hline & Total & 17.4 & 34.8 & 47.8 & 100 & 37.9 & 28.1 & 34 & 100 \\
\hline
\end{tabular}


The average conicity index value for the overall sample was $1.16 \pm 0.06$, with girls generally having higher indices than boys. Significant sex differences were found within the youngest four age groups (Table 2) but not for nine-year-old participants.

Average CIs reported in the age groups corresponding to five-, seven- and eight-yearolds were similar, with no statically significant differences emerging $(\mathrm{F}=0.82 ; p$-value $=0.479)$. Further, outcomes were significantly correlated with weight, waist circumference and body fat mass, but not with height (Table 4).

Table 4. Pearson correlation coefficients (r) between anthropometric variables.

\begin{tabular}{|c|c|c|c|c|c|c|}
\hline & & CI & Height (m) & Weight (kg) & wstC (cm) & BF\% \\
\hline CI & $\begin{array}{c}\mathrm{r} \\
p \text {-value }\end{array}$ & 1.00 & & & & \\
\hline Height (m) & $\begin{array}{c}\mathrm{r} \\
p \text {-value }\end{array}$ & $\begin{array}{l}0.07 \\
0.17\end{array}$ & 1.00 & & & \\
\hline Weight (kg) & $\begin{array}{c}\mathrm{r} \\
p \text {-value }\end{array}$ & $\begin{array}{c}0.19^{* *} \\
0.00\end{array}$ & $\begin{array}{c}0.87^{* *} \\
0.00\end{array}$ & 1.00 & & \\
\hline wstC (cm) & $\begin{array}{c}\mathrm{r} \\
p \text {-value }\end{array}$ & $\begin{array}{c}0.68 \text { ** } \\
0.00\end{array}$ & $\begin{array}{c}0.6^{* *} \\
0.00\end{array}$ & $\begin{array}{c}0.82 \text { ** } \\
0.00\end{array}$ & 1.00 & \\
\hline $\mathrm{BF} \%$ & $\begin{array}{c}\mathrm{r} \\
p \text {-value }\end{array}$ & $\begin{array}{c}0.47^{* *} \\
0.00\end{array}$ & $\begin{array}{c}0.32 * * \\
0.00\end{array}$ & $\begin{array}{c}0.51^{* *} \\
0.00\end{array}$ & $\begin{array}{c}0.66^{* *} \\
0.00\end{array}$ & 1.00 \\
\hline
\end{tabular}

** Note: Correlation significance level 0.01 (bivariate).

Participant conicity indices were similar regardless of whether the participants were classified as obese or overweight according to their BMI z-score, with no statistically significant differences emerging $\left(X^{2}=2.469 ; p\right.$-value $\left.=0.650\right)$. In contrast, participants who were classified as being at risk of being overweight presented conicity indices that were significantly lower than the aforementioned groups $\left(X^{2}=29.83 ; p\right.$-value $\left.=0.001\right)$. With regard to the distribution of participating schoolchildren according to $\mathrm{CI}$ intervals defined in association with BMI z-scores, the majority of participants had indices that fell within the 1.11 to $1.20 \mathrm{CI}$ interval, with fewer having indices between 1.21 and 1.30. The rest of the sample presented indices that fell into extreme categories that lacked significant representation (Table 3).

It is also of interest to consider the distribution of individuals classified as obese due to their waist circumference. In the case of boys, $\mathrm{CI}^{\prime}$ s were distributed within a confidence interval of 1.176 to 1.213 , whilst in the case of girls this interval ranged from 1.208 to 1.234. Remaining participants included in the categories for "at risk of abdominal obesity" and "normal weight" presented lower values (Table 5). In this way, the obtained confidence intervals permitted the determination of CI cut-points, with values greater than or equal to 1.176 and 1.208 in boys and girls, respectively, denoting the state of abdominal obesity. Abdominal obesity risk was denoted at values above 1.148 in both sexes, whilst lower values corresponded to the normal state.

Table 5. CI cut-points according to confidence intervals for identifying abdominal obesity in accordance with waist circumference.

\begin{tabular}{|c|c|c|c|c|c|c|}
\hline \multirow{2}{*}{$\begin{array}{l}\text { Classification According } \\
\text { to Waist Circumference }\end{array}$} & \multirow[t]{2}{*}{ Population } & \multirow[t]{2}{*}{$\mathbf{n}$} & \multirow{2}{*}{$\bar{X}$ and SD of CI } & \multirow{2}{*}{ Standard Error of the $\bar{X}$} & \multicolumn{2}{|c|}{$\begin{array}{l}\text { CI According to } \\
\text { Confidence Intervals }\end{array}$} \\
\hline & & & & & LOWER & UPPER \\
\hline \multirow{3}{*}{ Obese } & Males & 54 & $1.194 \pm 0.07$ & 0.009 & 1.176 & 1.213 \\
\hline & Females & 81 & $1.221 \pm 0.06$ & 0.007 & 1.208 & 1.234 \\
\hline & Overall & 135 & $1.210 \pm 0.06$ & 0.006 & 1.200 & 1.221 \\
\hline \multirow{3}{*}{ Abdominal obesity risk } & Males & 45 & $1.159 \pm 0.04$ & 0.006 & 1.148 & 1.172 \\
\hline & Females & 55 & $1.167 \pm 0.05$ & 0.006 & 1.155 & 1.180 \\
\hline & Overall & 100 & $1.164 \pm 0.04$ & 0.004 & 1.155 & 1.173 \\
\hline
\end{tabular}


Table 5. Cont.

\begin{tabular}{|c|c|c|c|c|c|c|}
\hline \multirow{2}{*}{$\begin{array}{l}\text { Classification According } \\
\text { to Waist Circumference }\end{array}$} & \multirow[t]{2}{*}{ Population } & \multirow[t]{2}{*}{$\mathbf{n}$} & \multirow[t]{2}{*}{$\bar{X}$ and SD of CI } & \multirow[t]{2}{*}{ Standard Error of the $\bar{X}$} & \multicolumn{2}{|c|}{$\begin{array}{c}\text { CI According to } \\
\text { Confidence Intervals }\end{array}$} \\
\hline & & & & & LOWER & UPPER \\
\hline \multirow{3}{*}{ Normal } & Males & 85 & $1.126 \pm 0.04$ & 0.004 & 1.118 & 1.136 \\
\hline & Females & 36 & $1.125 \pm 0.04$ & 0.007 & 1.112 & 1.138 \\
\hline & Overall & 121 & $1.126 \pm 0.04$ & 0.004 & 1.119 & 1.134 \\
\hline \multirow{3}{*}{ Overall } & Males & 184 & $1.154 \pm 0.06$ & 0.004 & 1.146 & 1.163 \\
\hline & Females & 172 & $1.184 \pm 0.06$ & 0.005 & 1.174 & 1.194 \\
\hline & Overall & 356 & $1.168 \pm 0.06$ & 0.003 & 1.162 & 1.175 \\
\hline \multicolumn{7}{|c|}{ Cut-Points for Diagnosis of Abdominal Obesity } \\
\hline Sex & \multicolumn{2}{|c|}{ Abdominal Obesity } & \multicolumn{2}{|c|}{ Abdominal Obesity Risk } & \multicolumn{2}{|c|}{ Normal } \\
\hline Male & \multicolumn{2}{|c|}{$\geq 1.17$} & \multicolumn{2}{|r|}{$1.14-1.16$} & \multicolumn{2}{|c|}{$<1.14$} \\
\hline Female & \multicolumn{2}{|c|}{$\geq 1.2$} & \multicolumn{2}{|r|}{$1.15-1.19$} & \multicolumn{2}{|c|}{$<1.15$} \\
\hline
\end{tabular}

Average fat mass percentage in the study sample was higher in girls than boys (Table 2) in all studied age groups. With regard to age groups, mass showed the lowest $\mathrm{BF} \%$ amongst five-year-old schoolchildren and the highest amongst six-year-old schoolchildren, with this group having a significantly greater proportion of body fat than the rest of the sample $(\mathrm{F}=1.275 ; p$-value $=0.028)$. Finally, $56.2 \%$ of study participants presented with a fat content that accounted for less than $20 \%$ of their body weight.

\section{Discussion}

Obtained outcomes showed that a significant correlation existed between height and weight, waist circumference and percentage body fat. This suggests that these factors may exert an influence on body fat content and the accumulation of abdominal fat. This situation has been previously reported by Remón Popa et al. [25] in male adults of different heights. Further, it is significant that the girls who participated in the present study were typically taller than the boys. This implies that the girls involved in the study had a greater capacity to support their total body mass against the forces of gravity. This finding is related to the genetic determinism of growth during the pre-pubertal period, with phenotypic weight plasticity known to be lacking due to exposure to non-endogenous stimuli [26].

Waist circumferences in the study population mostly pertained to the statuses of "obesity" or "at risk of abdominal obesity", with more girls being found in these groups than boys. Should these statuses be maintained, they would lead to an alarming prognosis within the examined schoolchildren, especially—and particularly amongst girls-when the modifications that occur to body and abdominal fat during biological maturity are considered. In this respect, Cordero and Cesani [27] and Harwood [28] have described the increased fat accumulation that takes place in the gluteofemoral region in girls from the onset of the pubertal period. This does not constitute a limiting factor for the continuity of abdominal fat stores, unlike in boys, who, according to Bojanic et al. [29] and Pérez Miguelsanz et al. [30], preserve their fat distribution in the abdominal zone, tending towards the loss of fat mass in the limbs and fat gains in the trunk.

According to Hernández et al. [9] and Sousa et al. [20], this dymorphic distribution seen in girls puts them at a greater risk of diabetes, prothrombosis and chronic low-grade inflammation. As outlined by Flores-Olivares et al. [31], this increases the likelihood of conditions becoming chronic in nature and extending into adulthood.

To what has been discussed above, it can be added that examination of abdominal obesity classifications according to waist circumference, alongside the distribution of nutritional status according to BMI z-score, produced statistically significant differences $\left(X^{2}=169.432 ; p\right.$-value $\left.=0.001\right)$. Further, a Cohen's kappa $(K)$ agreement of $35 \%$ was produced between the categories defined in both models, with a lower value being seen in girls $(\mathrm{K}=18.8 \%)$ than in boys $(\mathrm{K}=51.9 \%)$. In addition, a higher number of obese 
individuals were identified when using the waist circumference classification, whilst a meaningful proportion of those previously declared as overweight or at risk of being overweight according to their BMI z-score where denominated as having a normal status $(34.0 \%)$. This status does not constitute an isolated finding. In fact, it is in agreement with a study conducted by Pérez-Ríos et al. [32] with a sample of Galician children and adolescents, in which 4 of every 100 pupils diagnosed as normal weight actually presented with abdominal obesity.

The evidence presented above highlights the limitations of BMI when it comes to discriminating between body compartments, such as fat compartments and their localised distribution. In the opinion of Curilem Gatica et al. [4], BMI can, therefore, lead to misleading information about obesity risk, particularly for abdominal obesity. This same conclusion is held by other authors [33-35] who, on the whole, class it as a measure of low sensitivity, pointing to its negative implications in relation to the carrying out of nutritional diagnostic tests within this age group. These findings confirm that BMI and waist circumference measurements cannot be used interchangeably in the nutritional evaluation of children. On the other hand, they can be used in collaboration, with wstC being preferentially used as the main descriptor in children aged five to nine years, reflecting the way in which the continuous changes experienced during growth and development affect BMI and their classification.

Consequently, the criteria presented by Pérez-Ríos et al. [32] were upheld with respect to the fact that prevalence of excess weight, when evaluated independently from abdominal obesity, led to underestimation of nutritional status in the present study. As well as this, Torres-Zapata et al. [36] have highlighted the likelihood of not detecting the presence of obesity syndrome in normal weight individuals.

Despite the meaningfulness of the conicity index as an indicator of abdominal obesity, Arruda Neta et al. [19] highlight that it has had only a limited use in epidemiological studies. These authors suggest that the reason for this lies in the equation's calculation complexity, although Carneiro et al. [37] and Fariñas Rodríguez et al. [5] also mention the lack of cut-points when using this measure to conduct evaluations within youth populations.

It is notable that various authors have only found waist circumference and weight to be correlated with abdominal obesity [20,38]. This same condition was met in the present study, as statistically significant correlations were found when associating these two variables with estimated CIs, but not with height. This condition has been reported by other authors as a weak association that is highly desirable as an obesity indicator $[9,23]$.

In contrast, conicity index outcomes in the present study differed from those reported by Fariñas Rodríguez et al. [5], which suggested that significant differences did not exist according to sex or age. This same outcome was only found in the present work in nineyear-old schoolchildren, whilst girls aged between five and eight years presented higher $\mathrm{CI}$ values than boys. Another study reporting contrasting outcomes is that conducted by Barbosa et al. [39] in Brazilian and Venezuelan children aged between seven and nine years $[19,40]$. Unlike in the present study, these authors identified higher values for this indicator amongst boys.

With regard to the differences described above in comparison with other studies, it should not be ignored that the sample for the present study was selected with the main aim of including individuals who presented excess fat, according to their BMI. This same criterion was only applied in the research study conducted by Barbosa et al. [39] in Brazilian children. All other studies $[5,19,40]$ developed nutritional diagnostic tests, dependant on chronological age or biological maturity status, rather than on excess fat. In this previous research, values pertaining to the various bodily dimensions were generally found to be greater in boys than girls. Nonetheless, within the sample of schoolchildren captured in the present study as a unit of analysis, girls had greater height, weight and waist circumference dimensions than boys up until eight years of age. From eight years onwards, boys exceeded girls and, although girls continued to have slightly higher CIs at nine years, these differences were not statistically significant. Thus, from this age on, there 
was no evidence of higher values amongst girls, suggesting a possible sexual dymorphism from eight years onwards, something that has already been demonstrated in children from this region [26].

Aside from the aforementioned differences, it is evident that the average conicity index obtained for participants in the present study indicates the existence of a body shape that reflects the presence of fat stores in the abdominal region and the possible possession of a lipid plasma profile characterised by negative health indices. Such negative health indices are determined according to triaglyceride and LDL cholesterol levels, which hasten the emergence of diseases such as type 2 diabetes, obstructive sleep apnea, hypertension, dislipidemia and metabolic syndrome [19,41].

On the other hand, although the conicity index maintained a statistically significant correlation with the percentage of body fat in the present study, this correlation does not mean that $\mathrm{CI}$ increases are paired with $\mathrm{BF} \%$ increases. The present work produced evidence that children with percentage body fats of between $10 \%$ and $30 \%$ were largely concentrated within a CI range of 1.11 to 1.20 . In this way, the location of fat accumulation or abdominal adiposity determined differences between these children.

Finally, it is necessary to consider that the value of $20 \%$ body fat referred to by Hoyo and Sañudo [42] as a cut-point that determines excess fat in the infant population does not correspond with the outcomes reported in the present study. This is evidenced by the fact that all of the present participants diagnosed with excess fat presented excess fat in accordance with their BMI z-score, but only $40.4 \%$ of these exceeded the aforementioned fat percentage.

\section{Conclusions}

The population covered by the present sample showed a high prevalence of central obesity, or risk thereof, according to waist circumference and conicity index. Prevalence was higher amongst girls than boy, with girls also having a more negative plasma lipid profile with regard to health.

BMI failed to show significant agreement with nutritional status classification through waist circumference and may, therefore, conceal the existence of obesity syndrome when weight is considered to be normal.

In accordance with the cut-points identified for the study population, the conicity index represents a subsidary scale which can be used to identify central adiposity in evaluations of nutritional state according to BMI z-scores. In this way, it suggests a practical condition of use in circumstances when BMI is not combined with waist circumference for the nutritional diagnosis of individuals belonging to the infant population aged between five and nine years old and living in the coastal region of Ecuador.

Thus, diagnosis of the distribution and location of body fat accumulation permits identification of the existence of morbidity risk associated with the likely manifestation of metabolic syndrome. It is, therefore, necessary to include this diagnosis in studies examining body composition in children.

Author Contributions: Conceptualization, R.A.-M., D.H.-G. and M.L.-M.; data curation, R.A.-M. and D.L.-G.; methodology, D.H.-G., M.L.-M. and R.A.-M.; writing-original draft preparation, D.L.-G. and R.A.-M.; formal analysis, R.A.-M., D.H.-G. and M.L.-M.; investigation, R.A.-M., J.S.P.-A., J.G.P.-C. and D.H.-G.; writing—review and editing, D.H.-G., R.A.-M., M.L.-M., D.L.-G., J.S.P.-A. and J.G.P.-C. All authors have read and agreed to the published version of the manuscript.

Funding: Resources assigned by the Technical University of Manabí (UTM) to the following research project: Strategy for improving nutritional status in 5-9-year-old students attending state-funded and private schools in the north central coastal region of Ecuador. 
Institutional Review Board Statement: The study was carried out in accordance with the guidelines of the Declaration of Helsinki and was approved by the Institutional Bioethics Committee of the Technical University of Manabí with code UTM Folio AP-C1-2018-FCS-0003 and title of the project "strategy for improving nutritional status in 5-9-year-old students attending state and private schools in the north central coastal region of Ecuador"as of 30 October 2019.

Informed Consent Statement: Informed consent was obtained from all the subjects involved in the study.

Data Availability Statement: The data is not publicly available due to ongoing research.

Acknowledgments: We thank the students undertaking the sixth and seventh semesters of the Bachelor of Nutrition and Dietetics at the UTM and the lecturers responsible for orienting this specialty for their collaboration in the organization of fieldwork.

Conflicts of Interest: The authors declare no conflict of interest.

\section{References}

1. Crovetto-Mattassi, M.; Coñuecar-Silva, S. Publicidad alimentaria según grupos y sub-grupos de alimentos en la televisión de Chile. Nutr. Clin. Diet. Hosp. 2016, 36, 41-53. [CrossRef]

2. Díaz, J.; Espinoza-Navarro, O. Determinación del porcentaje de masa grasa, según mediciones de perímetros corporales, peso y talla: un estudio de validación. Int. J. Morphol. 2012, 30, 1604-1610. [CrossRef]

3. González-Jiménez, E. Composición corporal: Estudio y utilidad clínica. Endocrinol. Nutr. 2013, 60, 69-75. [CrossRef] [PubMed]

4. Curilem-Gatica, C.; Almagià-Flores, A.; Rodríguez-Rodríguez, F.; Yuing-Farias, T.; Berral de la Rosa, F.; Martínez-Salazar, C.; Jorquera-Aguilera, C.; Bahamondes-Ávila, C.; Soís-Urra, P.; Cristi-Montero, C.; et al. Evaluación de la composición corporal en niños y adolescentes: Directrices y Recomendaciones. Nutr. Hosp. 2016, 33, 734-738. [CrossRef]

5. Fariñas-Rodríguez, L.; Vázquez-Sánchez, V.; Fuentes-Smith, L.E.; Martínez-Fuentes, A. Índice de Conicidad en una muestra de niños cubanos, herramienta para estudios poblacionales. Rev. Cuba. Genética Comunitaria 2012, 6, 31-37. Available online: https:/ / www.medigraphic.com/pdfs/revcubgencom/cgc-2012/cgc122e.pdf (accessed on 12 December 2019).

6. Lamiquiz-Moneo, I.; Mateo-Gallego, R.; Bea, A.M.; Dehesa-García, B.; Pérez-Calahorra, S.; Marco-Benedí, V.; Baila-Rueda, L.; Laclaustra, M.; Civeira, F.; Cenarro, A. Genetic predictors of weight loss in overweight and obese subjects. Sci. Rep. 2019, 9, 10770. [CrossRef] [PubMed]

7. Pysna, J.; Pysny, L.; Cihlar, D.; Petru, D.; Skopek, M. Effect of Physical Activity on Obesity in Second Stage Pupils of Elementary Schools in Northwest Bohemia. Sustainability 2020, 12, 10042. [CrossRef]

8. Prazeres-Almeida, E.; Sabino-Pinho, C.P.; Dornelas-Leão, A.P.; Galvão-Rodrigues, I.; Silva-Diniz, A.; Kruze Grande de Arruda, I. Razón entre grasa visceral y subcutánea como predictor de alteraciones cardiometabólicas. Rev. Chil. Nutr. 2018, 45, 28-36. [CrossRef]

9. Hernández, R.J.; Mendoza, C.J.; Duchi, J.P. Índice de conicidad y su utilidad para detectar riesgo cardiovascular y metabólico. Revista Cubana de Endocrinología 2017, 28, 1-13. Available online: http:/ / scielo.sld.cu/scielo.php?script=sci_arttext\&pid=S1561-29 532017000100008 (accessed on 14 December 2019).

10. Pérez de José, A.; Verdalles-Guzmán, U.; Abad, S.; Vega, A.; Reque, J.; Panizo, N.; Rincón, A.; Yuste, C.; Arroyo, D.; López-Gómez, J.M. El síndrome metabólico se asocia con eventos cardiovasculares en hemodiálisis. Nefrología 2014, 34, 69-75. [CrossRef]

11. Barreto-Quintana, H.M.; Ferrer-Arocha, M.; Fernández Britto-Rodríguez, J.E.; Sierra-Ariza, I.D. Señales aterogénicas tempranas en niños entre 3 y 5 años de un círculo infantil de La Habana. Rev. Fac. Med. 2014, 62, 187-191. [CrossRef]

12. Ruiz-Sánchez, E.; Bañuelos-Barrera, Y.; Bañuelos-Barrera, P.; Álvarez-Aguirre, A.; Valles-Verdín, M.M.; Domínguez-Chávez, C.J. Porcentaje de grasa corporal en escolares y su asociación con el estilo de vida y macronutrientes. Rev. Cuid. 2015, 6, 1022-1028. [CrossRef]

13. Dornhoff, M.; Hörnschemeyer, A.; Fiebelkorn, F. Students' Conceptions of Sustainable Nutrition. Sustainability 2020, $12,5242$. [CrossRef]

14. Bonavolontà, V.; Cataldi, S.; Coluccia, A.; Giunto, A.; Fischetti, F. Sustainable Intervention for Health Promotion and Postural Control Improvement: Effects of Home-Based Oculomotor Training. Sustainability 2020, 12, 10552. [CrossRef]

15. López-Gil, J.F.; García-Hermoso, A.; Gomes-Sentone, R.; Israel-Caetano, C.; Renato-Cavichiolli, F.; Yuste-Lucas, J.L. Influence of Adiposity on Physical Activity in Schoolchildren: The Moderator Role of Adherence to the Mediterranean Diet. Sustainability 2020, 12, 6474. [CrossRef]

16. Fernández, J.R.; Redden, D.T.; Pietrobelli, A.; Allison, D.B. Waist circumference percentiles in nationally representative samples of African-American, European-American, and Mexican-American children and adolescents. J. Pediatr. 2004, 145, 439-444. [CrossRef]

17. Valdez, R.; Seidell, J.C.; Ahn, Y.I.; Weiss, K.M. A new index of abdominal adiposity as an indicator of risk for cardiovascular disease: A cross-population study. Int. J. Obes. 1993, 17, 77-82.

18. Mondal, H.; Mondal, S.; Baidya, C. Conicity index and a body shape index as predictor variable for cardiorespiratory fitness in healthy young adults. CHRISMED J. Health Res. 2018, 5, 133-136. [CrossRef] 
19. Neta, A.d.C.; Farias-Júnior, J.C.d.M.; Martins-Rodriguez, P.; Ferreira-Flávia, E.L.d.L. Índice de conicidade como preditor de alterações no perfil lipídico em adolescentes de uma cidade do Nordeste do Brasil. Cad. Saúde Pública 2017, 33, e00029316. [CrossRef]

20. Sousa, N.P.S.; Salvador, E.P.; Barros, A.K.; Polisel, C.G.; Carvalho, W.R.G. Anthropometric Predictors of Abdominal Adiposity in Adolescents. JEP Online 2016, 19, 66-76.

21. Organización Mundial de la Salud. Curso de Capacitación para la Evaluación de Crecimiento del Niño. 2008. Available online: https: / / www.who.int/childgrowth/training/es / (accessed on 26 October 2020).

22. Marfell-Jones, M.; Olds, T.; Stewart, A.; Carter, L. Normas Internacionales para la Valoración Antropométrica. Manual ISAK Potchefstroom: República de Sudáfrica. Sociedad Internacional para el Avance de la Cineantropometría (ISAK). 2015. Available online: https:/ / antrofor.files.wordpress.com/2020/02/manual-isak-2005-cineantropometria-castellano1.pdf (accessed on 17 January 2020).

23. Vasques, A.C.; Rosado, L.; Rosado, G.; Ribeiro, R.d.C.; Franceschini, S.; Geloneze, B. Indicadores antropométricos de resistencia a la insulina. Arq. Bras. Cardiol. 2010, 95, e14-e23. [CrossRef]

24. Alvero Cruz, J.R.; Cabañas Armesilla, M.D.; Herrero de Lucas, A.; Martinez Riaza, L.; Moreno Pascual, C.; Porta Manzañido, J.; Sillero Quintana, M.; Sirvent Belando, J.E. Protocolo de valoración de la composición corporal para el reconocimiento médico-deportivo. Documento de consenso del grupo español de cineantropometría de la Federación Española de Medicina del Deporte. Arch. Med. Dep. 2010, 139, 330-343. Available online: https://archivosdemedicinadeldeporte.com/articulos/upload/ Documento_de_consenso_330_139.pdf (accessed on 13 April 2020).

25. Remón-Popa, I.; González-Sotolongo, O.C.; Arpa-Gámez, C.Á. El índice cintura-talla como variable de acumulación de grasa para valorar riesgo cardiovascular. Rev. Cuba. Med. Mil. 2013, 42, 444-450. Available online: http:/ /scielo.sld.cu/scielo.php? script=sci_arttext\&pid=S0138-65572013000400004\&lng=es\&tlng=es (accessed on 26 October 2020).

26. Arencibia-Moreno, R.; Hernández-Gallardo, D.; Linares-Girela, D.; Párraga- Acosta, J.S.; Rodríguez-Véliz, R.I.; Linares-Manrique, M. Transición de la complexión ósea y el estado nutricional en escolares de Portoviejo, Ecuador. Nutr. Clín. Diet. Hosp. 2020, 40, 10-17. [CrossRef]

27. Cordero, M.L.; Cesani, M.F. Crecimiento, estado nutricional y composición corporal: Un estudio transversal sobre las manifestaciones del dimorfismo sexual en escolares de Tucumán, Argentina. Rev. Española Nutr. Hum. Dietética 2020, $24,50-60$. [CrossRef]

28. Harwood, H.J. The adipocyte as an endocrine organ in the regulation of metabolic homeostasis. Neuropharmacology 2012, 63, 57-75. [CrossRef]

29. Bojanic, D.; Ljubojevic, M.; Krivokapic, D.; Gontarev, S. Waist circumference, waist-to-hip ratio, and waist-to-height ratio reference percentiles for abdominal obesity among Macedonian adolescents. Nutr. Hosp. 2020, 37, 786-793. [CrossRef]

30. Pérez-Miguelsanz, M.J.; Cabrera-Parra, W.; Varela-Moreiras, G.; Garaulet, M. Distribución regional de la grasa corporal. Uso de técnicas de imagen como herramienta de diagnóstico nutricional. Nutr. Hosp. 2010, 25, 207-223. [CrossRef] [PubMed]

31. Flores-Olivares, L.A.; De-León-Fierro, L.G.; Jiménez-Ponce, B.P.; Ortíz-Rodríguez, B. Circunferencia de cintura en cuatro sitios y su relación con indicadores de obesidad en escolares de 6 a 11 años. CienciaUAT 2019, 13, 18-27. [CrossRef]

32. Pérez-Ríos, M.; Santiago-Pérez, M.I.; Leis, R.; Martínez, A.; Malvar, A.; Hervada, X.; Suanzes, J. Exceso ponderal y obesidad abdominal en niños y adolescentes gallegos. An. Pediatría 2018, 89, 302-308. [CrossRef] [PubMed]

33. Moser, D.C.; Back, I.; Kapp, A.; Reis, A.; Coelho-e-Silva, M.; Leite, N. Anthropometric measure and blood pressure in school children. J. Pediatr. 2013, 89, 243-249. [CrossRef]

34. Bautista-Rodríguez, M.L.; Guadarrama-Guadarrama, R.; Veytia-López, M. Prevalencia de obesidad según los indicadores: Porcentaje de grasa corporal, índice de masa corporal y circunferencia de cintura. Nutr. Clín. Diet. Hosp. 2020, 40, 18-25. [CrossRef]

35. Moreno, L.A.; Moliner-Urdiales, D.; Ruiz, J.; Mesana, M.I.; Vicente-Rodríguez, G.; Rodríguez, G.; Fleta, J.; León, J.F.; GarcíaFuentes, M.J.; Castillo, M.; et al. Five year trends on total and abdominal adiposity in Spanish adolescents. Nutr. Hosp. 2012, 27, 731-738. [CrossRef]

36. Torres-Zapata, A.E.; Zapata-Gerónimo, D.; Rivera-Domínguez, J.; Acuña-Lara, J.P. El obeso de peso normal. Rev. Salud Pública Nutr. 2018, 17, 25-31. [CrossRef]

37. Carneiro, A.K.; Santana, L.C.; Cunha, C.; Eickemberg, M.; De Almeida, P.; Barbosa, L. Anthropometric clinical indicators in the assessment of visceral obesity: An update. Nutr. Clín. Diet. Hosp. 2016, 36, 168-179. [CrossRef]

38. Bacopoulou, F.; Efthymiou, V.; Landis, G.; Rentoumis, A.; Chrousos, G.P. Waist circumference, waist-to-hip and waist-to-height ratio reference percentiles for abdominal obesity among Greek adolescentes. BMC Pediatrics 2015, 15, 1-9. [CrossRef]

39. Barbosa, L.; Chaves, O.C.; Ribeiro, R.d.C. Parámetros antropométricos y de composición corporal en la predicción del porcentaje de grasa y perfil lipídico en escolares. Rev. Paul. Pediatr. 2012, 30, 520-528. [CrossRef]

40. Pérez, B.; Landaeta-Jiménez, M.; Vásquez, M. Distribución de la adiposidad en adolescentes mediante el índice de conicidad. Act. Cien. Ven. 2000, 51, 244-251. Available online: https://www.analesdenutricion.org.ve/publicaciones/349.pdf (accessed on 28 October 2020).

41. Cook, S.; Kavey, R.E. Dyslipidemia and pediatric obesity. Pediatr. Clin. N. Am. 2011, 58, 1363-1373. [CrossRef]

42. Hoyo-Lora, M.; Sañudo-Corrales, B. Composición corporal y actividad física como parámetros de salud en niños de una población rural de Sevilla. Rev. Int. Cienc. Deporte 2007, 6, 56-62. [CrossRef] 